\title{
Penggunaan Peta Konsep Sebagai Media Pembelajaran Pkn Untuk Meningkatkan Kualitas Proses dan Hasil Belajar Siswa Kelas IV SD Negeri 09 Tebat Karai
}

\section{Iskandar}

SD Negeri 09 Tebat Karai

\begin{abstract}
Abstrak
Penelitian ini bertujuan untuk meningkatkan kualitas proses pembelajaran PKn dan hasil belajar siswa kelas IV SD Negeri 09 Tebat Karai melalui Penggunaan Peta Konsep untuk Meningkatkan Kualitas Pproses dan Hasil Belajar PKn Di Kelas IV SD Negeri 09 Tebat Karai. Penelitian yang dilakukan adalah Penelitian Tindakan Kelas (Classroom Action Research) yang dilaksanakan sebanyak dua siklus, setiap siklus melalui tahap perencanaan, pelaksanaan, observasi dan refleksi. Subjek penelitian adalah siswa kelas IV SD Negeri 09 Tebat Karai. Instrumen yang digunakan yaitu lembar observasi, lembar tes. Teknik pengumpulan data terdiri dari observasi, dokumentasi, tes. Data tes dianalisis dengan menggunakan rumus rata-rata nilai dan persentase ketuntasan belajar klasikal, sedangkan data observasi dianalisis dengan rata-rata skor, skor tertinggi, skor terendah, selisih skor dan kisaran nilai untuk tiap kriteria. Hasil yang dicapai dalam penelitian ini yaitu :1) pada siklus I diperoleh nilai rata-rata observasi guru sebesar 23.5 dengan kategori baik, rata-rata observasi siswa sebesar 19.5 dengan kategori baik, dan nilai rata-rata hasil belajar 61.75 dengan ketuntasan belajar klasikal sebesar 50\%. Pada sikus II rata-rata skor guru 32.5 dengan kriteria baik, rata-rata skor observasi siswa sebesar 25 dengan kategori baik dan nilai rata-rata hasil belajar 70.25 dengan ketuntasan belajar klasikal sebesar $75 \%$. Berdasarkan hasil penelitian tersebut dapat disimpulkan bahwa penggunaan peta konsep sebagai media pembelajaran PKn dapat meningkatkan kualitas proses dan hasil belajar siswa kelas IV SD Negeri 09 Tebat Karai.
\end{abstract}

Kata Kunci : Pembelajaran PKn, Peta Konsep, Kualitas Proses pembelajaran, Hasil belajar

\section{Pendahuluan}

Pendidikan Pancasila dan Kewarganegaraan (PKn) merupakan mata pelajaran yang digunakan sebagai wahana untuk melestarikan dan mengembangkan nilai-nilai luhur dan moral yang berakar pada budaya Bangsa Indonesia.

Berdasarkan peraturan pemerintah RI no. 19 tahun 2005 tentang Standar Nasional Pendidikan (SNP) pasal 6 ayat 1b dalam KTSP (2008) bahwa diantara cakupan pembahasan mata pelajaran PKn yakni menekankan pada peningkatan kesadaran dan wawasan peserta didik dalam upaya perbaikan sikap dan perilaku sehari-hari 
siswa baik dalam kehidupan bermasyarakat, berbangsa, dan bernegara. Pentingnya Pelajaran PKn bagi peserta didik menuntut seorang guru agar dapat menggali potensi siswa dalam memahami materi PKn guna menumbuhkan kemampuan untuk memenuhi tuntutan ilmu pengetahuan dan teknologi yang semakin canggih di era globalisasi ini. Selain itu untuk menyaring etika dan budi pekerti yang tidak patut untuk di contoh oleh orang timur terutama anak didik bangsa Indonesia. Berdasarkan pengamatan peneliti hasil belajar PKn di kelas IV SD Negeri 09 Tebat Karai belum memuaskan. Hal ini dapat dibuktikan dari rata- rata nilai ulangan harian yaitu 5,0 dan ketuntasan belajar klasikal sebesar 50\%. Kenyataan ini disebabkan karena guru menggunakan model pembelajaran yang tidak variatif, guru selalu menggunakan metode ceramah yang menyebabkan siswa menjadi tidak aktif, sibuk dengan pekerjaannya sendiri, dan sulit mengerti materi pembelajaran. Setelah dilakukan refleksi berdasarkan kekurangan yang dilakukan dalam pembelajaran, peneliti melakukan perbaikan pembelajaran dengan mengadakan penelitian tindakan kelas dengan judul "Penggunaan Peta Konsep Sebagai Media Pembelajaran PKn Untuk Meningkatkan Kualitas Proses dan Hasil Belajar Siswa Kelas IV SD Negeri 09 Tebat Karai"

Martin dalam Aldyandro (2009) mengungkapkan bahwa peta konsep merupakan petunjuk bagi guru, untuk menunjukkan hubungan antara ide-ide yang penting dengan rencana pembelajaran. Sedangkan menurut Arends dalam Aldyandro (2009) juga menuliskan bahwa penyajian peta konsep merupakan suatu cara yang baik bagi siswa untuk memahami dan mengingat sejumlah informasi baru. Dengan penyajian peta konsep yang baik maka siswa dapat mengingat suatu materi dengan lebih lama lagi. Peta konsep menekankan pengaruh pengetahuan yang dimiliki siswa terhadap pembelajaran yang akan diberikan kepada siswa selanjutnya. Belajar bermakna berlangsung jika seseorang secara sadar dan jelas dapat menghubungkan pengetahuan dengan konsep-konsep atau dalil-dalil yang relevan. Sedangkan belajar hafalan berlangsung ketika pengetahuan baru dimasukkan secara sembarang ke dalam struktur kognitif siswa dalam Muhaimin (1999). Selain itu, menurut Rohana (2009) peta konsep merupakan alat yang dapat digunakan untuk mengetahui sejauh mana kemampuan siswa dalam memahami suatu amteri ajar. Pembuatan peta konsep dalam proses pembelajarn memungkinkan siswa terlibat aktif dalam proses berpikir, membuar siswa terlatih dalam menghubungkan konsepkonsep yang dimilikinya sehingga dapat membantu dalam menyelesaikan persoalan dalam proses belajarnya.

Dalam hubungan dengan struktur kognitif, Ausubel dalam Dahar (2001) mengelompokkan belajar dalam dua kategori, yaitu belajar yang tidak bermakna (hafalan) dan belajar bermakna (pemahaman). Pada belajar yang tidak bermakna, materi diterima tanpa dicerna dan dikaitkan dengan informasi yang sudah diketahui sebelumnya sehingga informasi yang diterima mengambang dan terisolasi. Akibatnya informasi menjadi sulit untuk diingat kembali dalam jangka waktu yang lama dan sulit untuk dikaitkan dengan informasi yang sudah diketahui. Sebaliknya pada belajar bermakna, informasi yang diterima dicoba dihubungkan dengan informasi yang sudah diketahui sehingga terbentuk suatu jaringan yang lebih kompleks. Keterkaitan informasi pada jaringan membuat informasi tersebut dapat diingat dalam jangka waktu yang lama.

Ada beberapa langkah dalam membuat peta konsep Dahar (2001) yaitu:

"(1) memilih bacaan dari buku pelajaran, (2) menentukan konsep-konsep yang relevan, (3) mengurutkan konsep-konsep itu dari yang paling inklusif (umum) ke yang paling tidak inklusif (khusus) atau contoh-contoh, (4) menyusun konsep-konsep tersebut dalam satu bagan, konsep-konsep yang paling inklusif di letakkan di bagian atas atau di pusat bagan tersebut, dan (5) menghubungkan konsep-konsep itu dengan kata atau kata penghubung sehingga mempunyai arti." 
Kegunaan peta konsep bagi siswa dan guru menurut Narika, Y (2004) adalah :

a. Bagi Siswa

Kegunaan peta konsep bagi siswa adalah : (1) Dapat membantu siswa belajar; (2) Peta konsep dapat memungkinkan siswa lebih aktif, dan; (3) Menolong para siswa belajar bermakna.

b. Bagi Guru

Kegunaan peta konsep bagi guru adalah : (1) Membantu guru menyampaikan materi pembelajaran; (2) Sebagai alat evaluasi.

Berdasarkan uraian di atas, sangat jelas bahwa peta konsep berperan penting dalam usaha peningkatan hasil belajar siswa. Dengan peta konsep siswa akan dilatih untuk berpikir dan dituntut untuk mau memikirkan konsep-konsep atau kejadiankejadian yang telah mereka ketahui untuk dihubungkan dengan konsep yang telah diberikan oleh guru, sehingga dengan belajar seperti ini merupakan salah satu cara yang harus ditempuh untuk terlaksananya belajar bermakna. Dengan demikian siswa akan dapat memahami materi pelajaran dengan baik, sehingga siswa akan memperoleh hasil belajar yang baik.

Sudjana (2009) menjelaskan dimensi penilaian proses pembelajaran berkenaan dengan komponen-komponen yang membentuk proses pembelajaran dan keterkaitan atau hubungan diantara komponen-komponen tersebut. Komponen pembelajaran sebagai dimensi penilaian proses pembelajaran setidak-setidaknya mencakup : (1) tujuan pembelajaran; (2) bahan pembelajaran; (3) kondisi siswa dan kegiatan belajarnya; (4) kondisi guru dan kegiatan mengajarnya; (5) alat dan sumber belajar yang digunakan; (6) teknik dan cara pelaksanaan penilaian.

Hasil belajar adalah kemampuan-kemampuan yang dimiliki siswa setelah ia menerima pengalaman belajarnya. Hasil belajar digunakan oleh guru untuk dijadikan ukuran atau kriteria dalam mencapai suatu tujuan pendidikan. Hal ini dapat tercapai apabila siswa sudah memahami belajar dengan diiringi oleh perubahan tingkah laku yang lebih baik lagi.

\section{Metode}

Jenis penelitian ini adalah penelitian tindakan kelas (Classroom Action Research), yaitu merupakan suatu pencermatan terhadap kegiatan pembelajaran berupa sebuah tindakan, yang dimunculkan dan terjadi dalam sebuah kelas secara bersama. Arah dan tujuan penelitian tindakan ini yaitu demi kepentingan siswa dalam memperoleh hasil belajar yang memuaskan, Arikunto (2007).

Penelitian ini dilaksanakan di SD Negeri 09 Tebat Karai, subyek dari penelitian ini adalah seluruh siswa kelas IV yang berjumlah 20 Orang yang terdiri dari 12 siswa laki-laki dan 8 orang siswa perempuan. Pelaksanaan penelitian ini dilaksanakan pada bulan November tahun 2015.Teknik pengumpulan data dengan observasi, dokumentasi dan tes. Instrumen Penelitian yang digunakan adalah lembar observasi guru, lembar observasi siswa, dan lembat tes tertulis.

Ada empat tahapan penting dari penelitian tindakan ini yang terdiri dari : a) perencanaan (planning); b) pelaksanaan tindakan (action); c) pengamatan (observation); dan d) refleksi (reflection). Keempat tahap dalam penelitian tindakan kelas tersebut adalah unsur untuk membentuk sebuah siklus, yaitu satu putaran kegiatan beruntun yang kembali ke langkah semula. (Arikunto, 2006) 


\section{Hasil}

Siklus 1

\begin{tabular}{lc}
\hline Persentase Ketuntasan Belajar Klasikal & $\mathbf{5 0 \%}$ \\
\hline Rata-Rata Kelas & 60.75 \\
Skor Observasi Guru & 23.5 (Baik) \\
Skor Observasi Siswa & 19.5 (Baik \\
\hline
\end{tabular}

Untuk mengatasi aspek-aspek yang masih berada dalam kategori cukup pada siklus I sesuai dengan analisis data observasi guru dan siswa, maka langkah-langkah perbaikan yang dilaksanakan pada siklus II adalah sebagai berikut:

1) Guru sebaiknya memberikan apersepsi yang menarik bagi siswa dan menyangkut pengetahuan awal siswa dengan bercerita atau memberikan pertanyaan pemandu.

2) Guru sebaiknya membimbing siswa berdiskusi dalam kelompok.

3) Guru memberikan motivasi dan contoh cara melaporkan hasil diskusi yang baik

4) Guru memberi motivasi dan kesempatan siswa untuk bertanya

5) Guru membimbing siswa dalam menyimpulkan materi pelajaran.

Siklus II

\begin{tabular}{lc}
\hline Persentase Ketuntasan Belajar Klasikal & $\mathbf{7 5 \%}$ \\
\hline Rata-Rata Kelas & 70.25 \\
Skor Observasi Guru & 32.5 (Baik) \\
Skor Observasi Siswa & 25 (Baik \\
\hline
\end{tabular}

Berdasarkan hasil observasi guru dan siswa serta hasil evaluasi selama proses pembelajaran sudah menunjukkan peningkatan yang sangat baik. Hal ini dapat dilihat dari aspek pengamatan pada observasi guru rata-rata telah terlaksana dengan baik dan hanya ada 1 aspek yang dalam katagori cukup yaitu guru belum optimal memotivasi siswa untuk melaporkan hasil diskusi di depan kelas. Aktivitas siswa juga telah dalam katagori baik dengan rata- rata yang diperoleh sebesar 25 . Beberapa aspek yang ada di lembar observasi yang masih termasuk dalam kategori cukup pada siklus I, baik lembar observasi guru maupun lembar observasi siswa telah mengalami peningkatan pada siklus II. Adapun presentase ketuntasan belajar klasikal pada siklus I (50\%) meningkat pada siklus II menjadi (75\%).

\section{Pembahasan}

Peningkatan proses dan hasil pembelajaran PKn pada sub pokok bahasan sistem pemerintahan kecamatan dan provinsi dengan menerapkan peta konsep sebagai media pembelajaran dikarenakan media peta konsep dalam pembelajaran telah digunakan dengan optimal sehingga materi yang disampaikan menjadi bermakna. Hal tersebut sesuai dengan kegunaan peta konsep menurut Narika, Y (2004) yaitu : bagi siswa peta konsep ini dapat membantu siswa belajar, lebih aktif, dan belajar lebih bermakna. Sedangkan bagi guru peta konsep ini dapat membantu guru dalam menyampaikan materi pembelajaran dan bisa juga digunakan sebagai alat evaluasi.

Penerapan peta konsep sebagai media pembelajaran dapat meningkatkan hasil belajar siswa dalam memahami konsep PKn pada materi sistem pemerintahan kecamatan dan provinsi yang bersifat hafalan disebabkan peta konsep sangat cocok digunakan untuk materi yang bersifat hafalan, peta konsep sebagai media pembelajaran juga membantu siswa dalam memahami materi yang disampaikan oleh guru agar tidak mudah lupa dan akhirnya dapat meningkatkan hasil belajar 
siswa sehingga prestasi belajar siswa juga meningkat. Selain hasil belajar yang meningkat tingkah laku siswa di kelas juga sudah mengalami peningkatan. Siswa sudah bisa saling menghargai pendapat orang lain dan sudah dapat menerima perbedaan kemampuan dalam hal belajar siswa dan lebih sopan kepada setiap individu yang ada di kelas. Hal ini sesuai dengan cakupan mata pelajaran kewarganegaraan dan keperibadian atau PKn yang dimaksudkan untuk peningkatan kesadaran dan wawasan peserta didik akan status, hak, dan kewajiban dalam kehidupan bermasyarakat, berbangsa, dan bernegara, serta peningkatan kualitas dirinya sebagai manusia.

Akhirnya dapat simpulkan bahwa aktivitas pembelajaran dan hasil belajar telah berhasil dan mencapai ketuntasan yang ditetapkan SDN 09 Tebat Karai yaitu belajar dikatakan tuntas bila minimal $70 \%$ siswa mendapat nilai $\geq 60$ dan rata- rata kelas minimal 60, sehingga penelitian ini dapat diakhiri.

\section{Kesimpulan}

Berdasarkan hasil penelitian dan analisis data, maka dapat diambil kesimpulan antara lain :

1. Penggunaan peta konsep sebagai media pembelajaran PKn dapat meningkatkan kualitas proses pembelajaran. Hal ini dapat dilihat dari :

a. Aktivitas guru

Dengan menggunakan peta konsep sebagai media pembelajaran PKn yang dilakukan di kelas IV SD Negeri 09 Tebat Karai dapat meningkat. Pada siklus I nilai rata-rata aktivitas guru yaitu 23.5 dengan kriteria baik dan mengalami peningkatan pada siklus II menjadi 32.5 dengan kriteria baik.

b. Aktivitas siswa

Dengan menggunakan peta konsep sebagai media pembelajaran PKn yang dilakukan di kelas IV SD Negeri 09 Tebat Karai dapat meningkat. Pada siklus I nilai rata-rata aktivitas siswa yaitu 19.5 dengan kriteria baik dan mengalami peningkatan pada siklus II menjadi 25 dengan kriteria baik.

2. Penggunaan peta konsep sebagai media pembelajaran PKn dapat meningkatkan hasil belajar siswa kelas IV SD Negeri 09 Tebat Karai dengan ata-rata kelas pada siklus I sebesar 60,75 dengan ketuntasan belajar klasikal sebesar 50\% dan meningkat pada siklus II dengan nilai rata-rata 70.25 dan ketuntasan belajar secara klasikal mencapai $75 \%$.

\section{Saran}

1. Guru disarankan untuk dapat mencoba menggunakan peta konsep sebagai media pembelajaran PKn pada tingkatan kelas yang lain, karena terjadi peningkatan hasil belajar.

2. Guru disarankan untuk dapat mencoba menggunakan peta konsep sebagai media pembelajaran pada mata pelajaran yang lain agar dapat memberikan variatif baru dalam proses pembelajaran sebagai upaya untuk tercapainya tujuan pembelajaran yang diharapkan.

3. Bagi peneliti lain disarankan agar dilakukan penelitian lebih lanjut mengenai pembelajaran dengan menggunakan peta konsep sebagai media pembelajaran PKn. Peneliti mengemukakan masih terdapat beberapa kekurangan dalam penelitian ini, diharapkan bagi peneliti lain kekurangan ini nantinya dapat dijadikan bahan rujukan untuk melakukan penelitian selanjutnya. Kekurangan itu diantaranya guru belum optimal menciptakan motivasi siswa untuk melaporkan hasil diskusi di depan kelas 


\section{Referensi}

Aldyandro. 2009. Pengertian Concept Mapping. www. Google. Com.

Arikunto. 2007. Prosedur Penelitian Suatu Pendekatan Praktik. Jakarta : Renika. -2006. Penelitian Tindakan Kelas. Jakarta : Bumi Asksara

Dahar. 2001. Teori-Teori Belajar. Jakarta : Erlangga.

Muhaemin. 1999. Efektivitas Penggunaan Peta Konsep IPA Pada Sekolah Dasar Di Kotamadya Bandar Lampung. Makalah Yang Disampaikan Pada : Seminar Hasil Penelitian BKS-PTN Wilayah Barat Bidang Ilmu Pendidikan, 10-11 Mei 1999.

Narika, Y. 2004. Penerapan Peta Konsep Yang Dikombinasikan Dengan Metode Demonstrasi Dalam Pembelajaran Kimia Untuk Meningkatkan Prestasi Siswa Pada Konsep Materi Dan Perubahannya Di Kelas 1 SMU Pembangunan Kota Bengkulu. Skripsi UNIB.

Rohana. 2009. Penggunaan Peta Konsep Dalam Pembelajaran Statistika Dasar Di Program Studi Pendidikan Matematika FKIP Universitas PGRI Palembang. Diakses di http://eprints.unsri.ac.id

Sudjana, N. 2009. Penilaian Hasil Proses Belajar Mengajar. Bandung : Remaj Rosdakarya. 